\title{
Z-DNA-specific Antibodies in Human Systemic
}

\section{Lupus Erythematosus}

\author{
Eileen M. Lafer, Rosaura P. C. Valle, Achim Möller, Alfred Nordheim, \\ Peter H. Schur, Alexander Rich, and B. David Stollar, Department of \\ Biochemistry and Pharmacology, Tufts University School of Medicine, \\ Boston, Massachusetts 02111; Department of Biology, Massachusetts Institute \\ of Technology, Cambridge, Massachusetts 02139; Department of Medicine, \\ Robert B. Brigham Division of the Brigham and Women's Hospital, Harvard \\ Medical School, Boston, Massachusetts 02115
}

\begin{abstract}
A B S T R A C T Naturally occurring antibodies to lefthanded Z-DNA have been shown to be present in the sera of human patients with systemic lupus erythematosus (SLE). These antibodies are of two types. One type reacts with both denatured DNA and Z-DNA. The other type is specific for Z-DNA and remained in the serum after removal of the cross-reactive antibody by extensive absorption on a denatured DNA affinity column. The antibodies appear to be specific for SLE and do not appear frequently in other rheumatic diseases. The presence of the antibody in SLE is correlated with the clinical manifestations of the disease, in parallel with antibodies to native and denatured DNA.
\end{abstract}

\section{INTRODUCTION}

Systemic lupus erythematosus $(\mathrm{SLE})^{1}$ is characterized by a wide range of abnormal serological phenomena including autoantibody production (1-3), depression of complement components (4), and circulating as well as tissue deposited immune complexes (5). SLE sera contain antibodies that react with nucleic acids, nucleoproteins, and cell-surface antigens. Among the antinucleic acid family of antibodies, reactivity has been demonstrated with native DNA (nDNA), denatured DNA (dDNA), and double-stranded RNA (reviewed

Dr. Lafer's current address is Department of Biology, Massachussetts Institute of Technology, Cambridge, MA 02139.

Received for publication 6 July 1982.

1 Abbreviations used in this paper: dDNA, denatured DNA; JRA, juvenile rheumatoid arthritis; nDNA, native DNA; OA, osteoarthritis; RA, rheumatoid arthritis; SLE, systemic lupus erythematosus; SS; Sjögren's syndrome. in reference 6), transfer, ribosomal, and viral RNA (7-9), and poly (ADP-ribose) (10).

Some of the anti-dDNA antibodies are directed against purine or pyrimidine bases, or sequences of bases up to a length of five or six (6). These antibodies will not react with nDNA since the bases are buried within the helix and are sterically inaccessible. Another group of anti-dDNA antibodies are directed against the phosphate backbone; some of them also react with phospholipids, including cardiolipin, which contains two phosphodiester linked side chains separated by three carbon atoms (11). The antibodies that react with nDNA probably recognize the deoxyribosephosphate backbone. These antibodies also recognize helical regions in dDNA (12).

With the discovery of a new type of helical nucleic acid structure, the left-handed Z-DNA helix (13-14), the demonstration of its immunogenicity (15) and its presence in biological material (16), we undertook a study of the existence of naturally occurring anti-ZDNA antibodies in SLE. We previously identified ZDNA-binding antibodies in sera of the autoimmune MRL/1pr mice (15). In this study we have characterized such autoantibodies from human SLE patients.

Left-handed Z-DNA presents a unique antigenic structure. Portions of the bases are exposed on the surface of the Z-helix, in sharp contrast to the B-DNA helix, where the stacked bases are at the bottom of the two grooves. Further, the phosphate groups of Z-DNA are organized in a zig-zag pattern rather than a smooth spiral. One might then expect that in addition to a group of antibodies that see the zig-zag backbone, antibodies that recognize bases might also react with the surface of the Z-helix.

This paper establishes that naturally occurring antibodies to Z-DNA occur in human SLE sera. These 
antibodies are of the two types described above. One type reacts with both dDNA and Z-DNA, and may recognize the bases that are exposed in both structures or some common feature of the sugar-phosphate backbone. The other type is specific for Z-DNA; it was separated from the cross-reactive antibody by extensive absorption of the latter on a dDNA affinity column.

\section{METHODS}

\section{Materials}

Reagents. $\mathrm{Br}$-poly (dG-dC) - poly (dG-dC) (Z-DNA) was prepared as described (15) and was shown to have the ultraviolet absorbance and circular dichroism spectra characteristic of Z-DNA. Poly (dG-dC) - poly (dG-dC) was purchased from P-L Biochemicals, Inc., Milwaukee, WI. The above polymers were radiolabeled by nick-translation with $\left[{ }^{3} \mathrm{H}\right] \mathrm{dCTP}$ and $\left[{ }^{3} \mathrm{H}\right] \mathrm{dGTP}$ purchased from Amersham Corp., Arlington Heights, IL (17). [ $\left.{ }^{3} \mathrm{H}\right]$ Thymidine-labeled DNA was prepared from a mutant Escherichia coli, B3, as previously described (18). The DNA was treated with S1 nuclease before being used in radioimmunoassay. SLE sera were collected from patients at the Robert B. Brigham Hospital.

\section{Radioimmunoassay}

20- $\mu$ l samples of serum were diluted in $0.06 \mathrm{M} \mathrm{Na-phos-}$ phate $0.03 \mathrm{M}$ Na-EDTA, pH 8.0 (for binding to dDNA and nDNA) or $0.06 \mathrm{M} \mathrm{Na}$-phosphate, $0.03 \mathrm{M}$ EDTA, $0.2 \mathrm{M} \mathrm{NaCl}$ pH 8.0 (for binding to Z-DNA) to $100 \mu \mathrm{l}$. $100 \mathrm{ng}$ of ${ }^{3} \mathrm{H}$ labeled antigen in $50 \mu \mathrm{l}$ was added and incubated for $60 \mathrm{~min}$ at room temperature. Z-DNA binding was measured in the presence of $0.2 \mathrm{M} \mathrm{NaCl}$ to ensure that the antigen was com- pletely left-handed. nDNA and dDNA binding were measured under optimum conditions in which no $\mathrm{NaCl}$ was added to the assay buffer. $100 \mu$ l of a concentrated gamma globulin fraction of goat anti-human immunoglobulin serum was added, and the incubation continued for another hour. The resulting precipitate was centrifuged, washed with 0.06 $\mathrm{M}$ phosphate, $0.03 \mathrm{M}$ EDTA (+0.2 M NaCl for Z-DNA), $\mathrm{pH}$ 8.0 , dissolved in $0.2 \mathrm{ml}$ of $0.1 \mathrm{~N} \mathrm{NaOH}$ and counted in $3 \mathrm{ml}$ of Beckman Ready-Solv HP in Beckman mini-vials (Beckman Instruments, Inc., Fullerton, CA).

\section{Column absorption}

A dDNA-agarose column was prepared (K. Smith and B. D. Stollar, unpublished observation) using $1 \mathrm{mg} \mathrm{DNA} / \mathrm{ml}$ of affi-gel 102 (Bio-Rad Laboratories, Richmond, CA) and a water-soluble carbodiimide reagent. $3 \mathrm{ml}$ of each sample of serum was centrifuged at $27,000 \mathrm{~g}(15,000 \mathrm{rpm})$ for 45 min and brought to a final concentration of $20 \mathrm{mM}$ EDTA to inhibit nucleases. $5 \mathrm{ml}$ of gel were added to each sample and shaken for $2 \mathrm{~h}$ at room temperature and overnight at $4^{\circ} \mathrm{C}$. Columns were poured into $10-\mathrm{ml}$ syringes and the unabsorbed material was collected by washing the column with phosphate-buffered saline (PBS) (10 mM sodium phosphate, pH $7.4,140 \mathrm{mM} \mathrm{NaCl}$ ). It was concentrated to the original serum volume by ultrafiltration under pressure with an Amicon YM membrane. The absorption was repeated twice more and the final unbound serum protein was concentrated to the original serum volume again. Bound antibody was eluted with $20 \mathrm{mM}$ sodium carbonate, pH 10.5, 5\% DMSO (dimethyl sulfoxide) (16), dialyzed against PBS, and concentrated by ultrafiltration to twice the original serum volume.

\section{RESULTS}

Screening of patient sera. 49 samples of sera collected from 10 patients through 19 cycles of clinically



Figure 1 Direct binding radioimmunoassay of a $1 / 5$ dilution of each serum reacting with 100 $\mathrm{ng}$ of $\left[{ }^{3} \mathrm{H}\right] \mathrm{Br}$-poly $(\mathrm{dG}-\mathrm{dC}) \cdot \operatorname{poly}(\mathrm{dG}-\mathrm{dC})(\mathrm{Z}-\mathrm{DNA})$ in $0.06 \mathrm{M}$ sodium phosphate, $0.03 \mathrm{M}$ sodium EDTA, $0.2 \mathrm{M} \mathrm{NaCl}, \mathrm{pH}$ 8.0. 



active SLE were tested for binding to $\left[{ }^{3} \mathrm{H}\right] \mathrm{Z}-\mathrm{DNA}[\mathrm{Br}$ poly (dG-dC) • poly (dG-dC)], $\left[{ }^{3} \mathrm{H}\right] \mathrm{nDNA}$ and $\left[{ }^{3} \mathrm{H}\right] \mathrm{dDNA}$. All patients fulfilled four or more criteria for SLE as defined by the American Rheumatism Association (19). Stage I denotes the time when a patient was considered clinically stable, without evidence of active disease; stage II the time when a patient displayed the first evidence of clinical activity; stage III the time when the patient was considered to have maximal clinical renal or extrarenal exacerbations, and stage IV denotes the time of maximal clinical improvement or return of relative clinical stability (20).

A comparison was made with sera obtained from 50 patients with rheumatoid arthritis (RA), 34 patients with Sjögren's syndrome (SS), 8 patients with juvenile rheumatoid arthritis (JRA), 12 patients with scleroderma, 19 patients with osteoarthritis (OA), and 43 normal sera obtained from the Red Cross.

Significant amounts of anti-Z-DNA antibody were found in $>90 \%$ of the SLE samples tested during all stages of clinical activity (Fig. 1 ). The average binding had a maximum value of $19.4 \%$ at stage II, followed by $16,12.9$, and $11.8 \%$ at stages III, I, and IV respectively. Normal sera displayed an average binding of $3.3 \%$, which was similar to that seen in sera from patients with RA, SS, JRA, scleroderma, and OA. A small number of sera from patients with RA, scleroderma, and JRA showed binding above the normal background (greater than mean value of normals $+2 \mathrm{SD}$ ).

Although anti-Z-DNA antibody reactions were measured with sera from all stages of disease activity (Fig. 1), tests of serial samples from individual patients (Fig. 2) often revealed a distinct correlation between clinical disease activity and antibody reaction. In most cases, the nucleic acid binding was maximal at stage II or III (the time when the patient displayed maximal clinical exacerbation) and minimal at stages I and IV, when the patient displayed clinical stability (Fig. 2).

Separation of antibody populations. A dDNAagarose column was prepared and serum from three patients was extensively absorbed on the column. The binding of individual serum samples to radiolabeled nucleic acid antigens was measured before and after absorption. With one serum (Fig. 3A) $0.06,0.45$ and 1.7 aborbance $(\mathrm{A})_{280}$ units in $100 \mu \mathrm{l}$ were required to bind $20 \%$ of a $100-n g$ sample of radiolabeled dDNA, Z-DNA, or nDNA, respectively. No binding was seen

Figure 2 Direct binding radioimmunoassay of a $1 / 5 \mathrm{di}-$ lution of serial samples of sera from patients $A$ (panel $A$ ), $\mathrm{T}$ (panel B) and $\mathrm{V}$ (panel C) reacting with $100 \mathrm{ng}$ of $\left[{ }^{3} \mathrm{H}\right] \mathrm{Br}$ poly (dG-dC) - poly (dG-dC) (Z-DNA) (๑) in $0.06 \mathrm{M}$ sodium phosphate, $0.03 \mathrm{M}$ sodium EDTA, $0.2 \mathrm{M} \mathrm{NaCl} \mathrm{pH} 8.0$, $\left[{ }^{3} \mathrm{H}\right]$ nDNA $(\mathrm{O})$ and $\left[{ }^{3} \mathrm{H}\right] \mathrm{dDNA}(\Delta)$ in $0.06 \mathrm{M}$ sodium phosphate, $0.03 \mathrm{M}$ sodium EDTA, pH 8.0. 


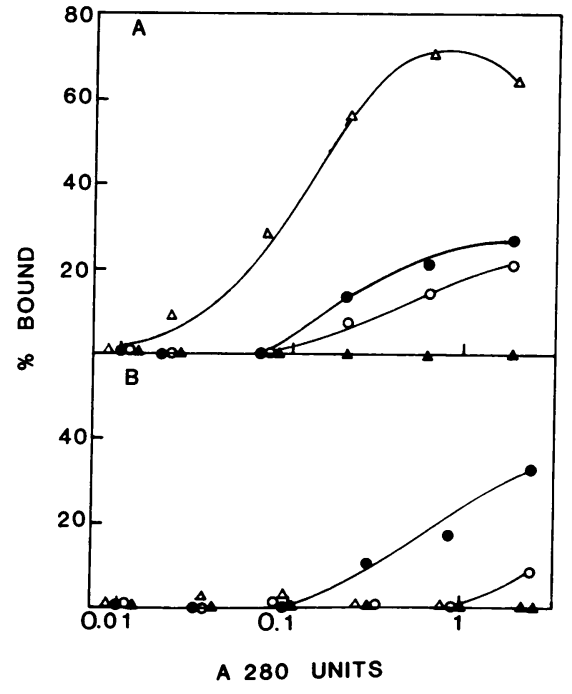

Figure 3 Direct binding radioimmunoassay of serial dilutions of whole serum (panel A) or dDNA-absorbed serum (panel B) of patient $\mathrm{F}$ to $100 \mathrm{ng}$ of $\left[{ }^{3} \mathrm{H}\right] \mathrm{Br}$-poly $(\mathrm{dG}-\mathrm{dC}) \cdot$

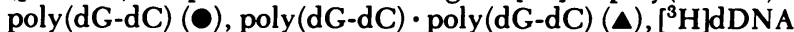
$(\Delta)$ and $\left[{ }^{3} \mathrm{H}\right] \mathrm{nDNA}(\mathrm{O})$ in $0.06 \mathrm{M}$ sodium phosphate, $0.03 \mathrm{M}$ sodium EDTA, $0.2 \mathrm{M} \mathrm{NaCl} \mathrm{pH} \mathrm{8.0.} \mathrm{To} \mathrm{compensate} \mathrm{for} \mathrm{pos-}$ sible losses and volume changes during absorption and concentration, serum samples were compared on the basis of protein content ( $\mathbf{A}_{280}$ units) in measured volumes.

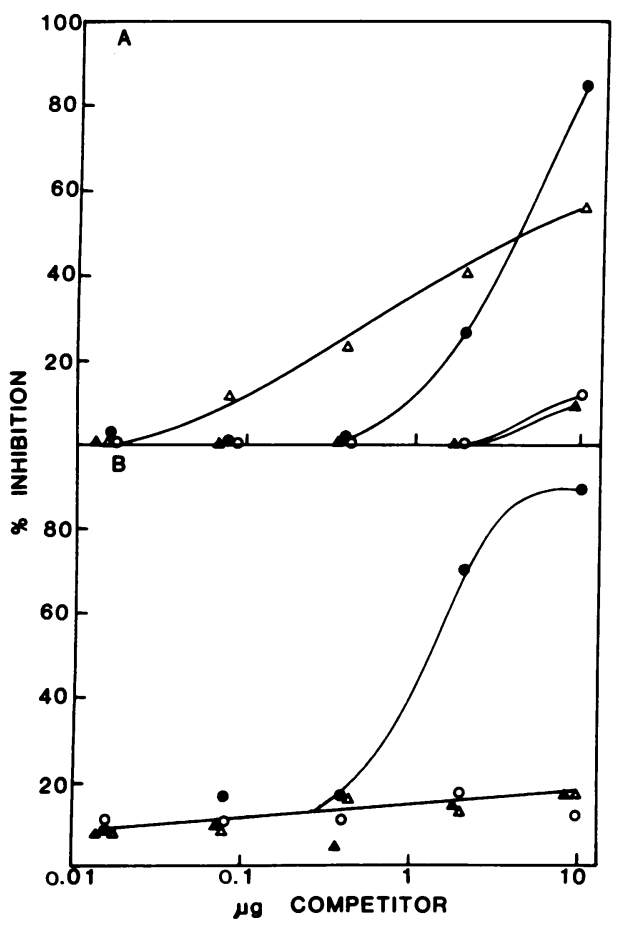

to poly (dG-dC) - poly (dG-dC) (right-handed) with up to $2.0 \mathrm{~A}_{280}$ units of serum. After extensive absorption on a dDNA column, $>99 \%$ of the dDNA-binding activity was removed, whereas $30-50 \%$ of the Z-DNAbinding activity remained in the serum (Fig. 3B); a small amount of binding to nDNA was observed with only the highest concentration of absorbed serum. A similar pattern was seen with the other two absorbed sera (data not shown). In all cases, a significant portion of the Z-DNA binding activity remained after virtually all the dDNA binding was removed. Antibody that was bound to the column and recovered by elution with $20 \mathrm{mM}$ sodium carbonate $\mathrm{pH} 10.5,5 \%$ DMSO bound dDNA, but not Z-DNA at the highest concentration that could be tested; the yield of anti-dDNA activity, however, was $<20 \%$.

The specificity of the Z-DNA binding populations in the absorbed and unabsorbed sera were compared by competitive radioimmunoassay using $\left[{ }^{3} \mathrm{H}\right] \mathrm{Z}$-DNA as the labeled antigen (Fig. 4). With unabsorbed serum F, dDNA was a stronger competitor than Z-DNA even when labeled Z-DNA was bound (Fig. 4A), indicating that much of this Z-DNA binding was due to crossreacting antibody. nDNA did not compete for this binding to Z-DNA, indicating that the antibodies that bound Z-DNA were distinct from those that bound to

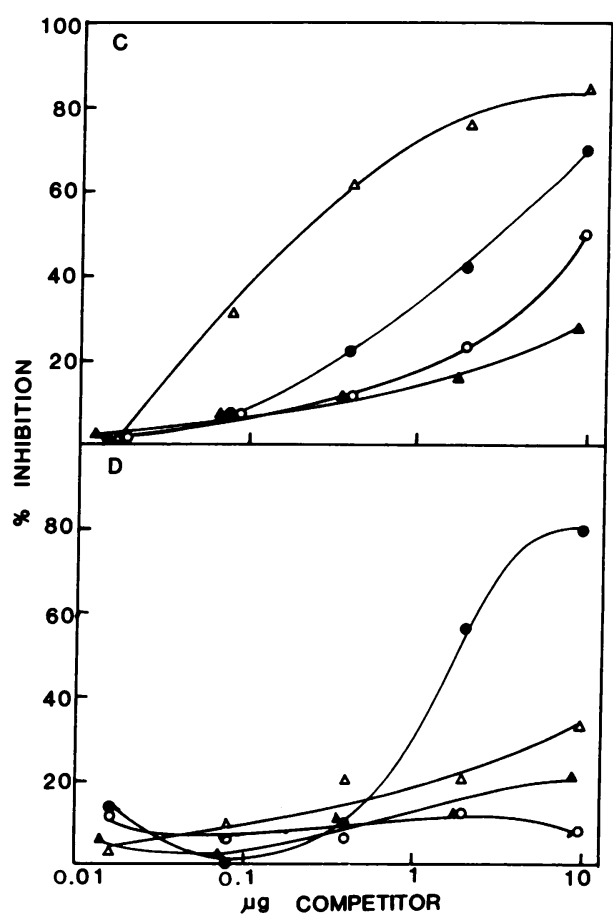

Figure 4 Competitive radioimmunoassay with whole serum (panels $A$ and $C$ ) or dDNA-absorbed serum (panels $B$ and D) of patient F (panels $A$ and $B$ ) and patient $S$ (panels $C$ and D). The binding to $100 \mathrm{ng}\left[{ }^{3} \mathrm{H}\right] \mathrm{Br}$-poly $(\mathrm{dG}-\mathrm{dC}) \cdot$ poly $(\mathrm{dG}-\mathrm{dC})$ was competed for by unlabeled $\mathrm{Br}$ poly $(\mathrm{dG}-\mathrm{dC}) \cdot \operatorname{poly}(\mathrm{dG}-\mathrm{dC})(\mathrm{Z}$-form $)(\bullet)$, poly $(\mathrm{dG}-\mathrm{dC}) \cdot \operatorname{poly}(\mathrm{dG}-\mathrm{dC})(\mathrm{B}-$ form $)(\Delta)$, dDNA $(\Delta)$ and nDNA $(O)$ in $0.06 \mathrm{M}$ sodium phosphate, $0.03 \mathrm{M}$ sodium EDTA, $0.2 \mathrm{M} \mathrm{NaCl} \mathrm{pH} 8.0$. 
nDNA. After absorption of anti-dDNA antibody from the serum, the residual binding to labeled Z-DNA was specifically inhibited by Z-DNA and not by dDNA (Fig. 4B). No competition was caused by $\mathrm{nDNA}$ or poly $(\mathrm{dG}-\mathrm{dC}) \cdot$ poly $(\mathrm{dG}-\mathrm{dC})$ (Fig. 4B). The unmasking of specificity for Z-DNA competitive immunoassay was also seen with absorbed serum of patient $S$ (Fig. $4 C, D)$ and with that of patient $\mathrm{H}$ (data not shown).

Ionic strength dependence of the anti-Z-DNA antibody reaction. Because Z-DNA formation is favored by high ionic strength (15-16) and rabbit anti-Z-DNA antibodies did bind the antigen in $4.0 \mathrm{M} \mathrm{NaCl}$, the effect of ionic strength on the SLE anti-Z-DNA antibody reaction was measured for 10 unabsorbed and 3 absorbed sera (Table I). All samples were reactive in $0.2 \mathrm{M} \mathrm{NaCl}$. Of the unabsorbed sera tested in $\mathbf{1 . 5}$ or $4.0 \mathrm{M} \mathrm{NaCl}$, five samples had no significant reaction, four samples had a reduced but significant reaction, and one sample enhanced reaction. None of the absorbed sera were reactive in high salt, although two of their unabsorbed counterparts displayed reduced, but significant reactivity.

\section{DISCUSSION}

These experiments firmly establish the existence of naturally occurring antibodies to Z-DNA in human SLE, extending the previously described findings in murine SLE (15). The antibodies appear to be as specific for SLE as other anti-nucleic acid antibodies and do not appear frequently in the other rheumatic diseases examined. A small number of sera from patients

TABLE I

Effect of Ionic Strength on the Binding of Z-DNA by SLE Sera and dDNA-Agarose-absorbed Sera

\begin{tabular}{|c|c|c|c|}
\hline \multirow[b]{2}{*}{ Serum sample } & \multicolumn{3}{|c|}{$\% \mathrm{Z}^{\mathrm{D}-\mathrm{DNA}}{ }^{\bullet}$ Bound in solutions containing } \\
\hline & $0.2 \mathrm{M} \mathrm{NaCl}$ & $1.5 \mathrm{M} \mathrm{NaCl}$ & $4.0 \mathrm{M} \mathrm{NaCl}$ \\
\hline$A-40 \rrbracket$ & 39.3 & 6.8 & 0.8 \\
\hline $\mathrm{T}-53$ & 25.6 & 0 & 0 \\
\hline V-68 & 24.3 & 30.9 & 45.1 \\
\hline C-74 & 25.6 & 10.0 & 18.9 \\
\hline Q-116 & 23.9 & 0.2 & 0 \\
\hline D-121 & 34.0 & 0.2 & 0 \\
\hline A-129 & 21.4 & 1.6 & 1.6 \\
\hline $\mathbf{H}$ & 39.0 & 3.6 & 0 \\
\hline $\mathrm{H}_{\mathrm{abs}}$ & 20.5 & 0 & 0 \\
\hline $\mathbf{S}$ & 47.8 & 19.8 & 20.2 \\
\hline $\mathrm{S}_{\mathrm{abs}}$ & 20.5 & 0 & 0 \\
\hline $\mathbf{F}$ & 48.4 & 10.7 & 4.9 \\
\hline$F_{\text {abs }}$ & 21.0 & 0 & $\mathbf{0}$ \\
\hline
\end{tabular}

- ${ }^{3} \mathrm{H}$-labeled $\mathrm{Br}$-poly(dG-dC) poly(dG-dC).

$\ddagger 20 \mu \mathrm{l}$ of serum or absorbed serum concentrated to original serum volume. with RA, scleroderma, and JRA did give a reaction above background. These serum samples also reacted with dDNA and nDNA. The presence of antibody in SLE is correlated with the clinical manifestations of the disease since antibodies were usually maximal during the stages of active clinical disease activity. The anti-Z-DNA antibody activity closely parallels that of anti-nDNA and anti-dDNA, but is generally lower.

Evidence from competitive radioimmunoassay indicates that there are two types of $\mathrm{Z}$-DNA reactive antibodies. One type, which is retained on a dDNA affinity column, is reactive with both dDNA and ZDNA since the binding of $\left[{ }^{3} \mathrm{H}\right] \mathrm{Z}-\mathrm{DNA}$ is competed for by both Z-DNA and dDNA. This type of antibody probably recognizes features of the bases that are exposed in both dDNA as well as on the surface of a ZDNA helix but are inaccessible in a B-DNA helix. In some cases this type of antibody is also reactive in high salt solution; its removal by absorption eliminated Z-DNA reactions of the sera in high salt. Some of the cross-reactive antibody may also recognize features of the backbone that are present in both Z-DNA and in the variable structure of denatured DNA. Failure to detect cross-reactive antibody in material eluted from the column with $20 \mathrm{mM}$ sodium carbonate $\mathrm{pH}$ 10.5, 5\% DMSO probably resulted from dilution and incomplete recovery; the initial level of activity was low, and the recovery of anti-dDNA activity was $<20 \%$. The other type of $Z$-DNA reactive antibody is probably specific for the Z-DNA backbone. It was left behind after extensive absorption of the serum on a dDNA column. The binding of this antibody to $\left[{ }^{3} \mathrm{H}\right] \mathrm{Z}$ DNA is competed for only by Z-DNA and not by dDNA, nDNA, or poly $(\mathrm{dG}-\mathrm{dC}) \cdot \operatorname{poly}(\mathrm{dG}-\mathrm{dC})$ in the $B$ form. The phosphate backbone is probably an important part of the antigenic determinant (Fig. 5) since the antibody reaction is sensitive to ionic strength.

The naturally occurring antibodies to Z-DNA differ from those produced by immunization with either $\mathrm{Br}$ poly $(\mathrm{dG}-\mathrm{dC}) \cdot \operatorname{poly}(\mathrm{dG}-\mathrm{dC})(15)$ or $\operatorname{poly}\left(\mathrm{dG}-\mathrm{dm}^{5} \mathrm{C}\right) \cdot$ poly $\left(\mathrm{dG}-\mathrm{dm}^{5} \mathrm{C}\right)(21)$. The induced antibodies do not cross-react with dDNA, as did one type of SLE autoantibody. Further, the induced antibodies react with $\mathrm{Br}$-poly (dG-dC) - poly (dG-dC) in $0.2 \mathrm{M} \mathrm{NaCl}$, poly (dG$\left.\mathrm{dm}^{5} \mathrm{C}\right) \cdot \operatorname{poly}\left(\mathrm{dG}-\mathrm{dm}^{5} \mathrm{C}\right)$ in $1.5 \mathrm{M} \mathrm{NaCl}$ and unmodified poly $(\mathrm{dG}-\mathrm{dC}) \cdot \operatorname{poly}(\mathrm{dG}-\mathrm{dC})$ in $4.0 \mathrm{M} \mathrm{NaCl}$. All three dDNA absorbed SLE sera reacted with $\mathrm{Br}$-poly(dG$\mathrm{dC}) \cdot \operatorname{poly}(\mathrm{dG}-\mathrm{dC})$ in $0.2 \mathrm{M} \mathrm{NaCl}$ but not with dDNA or the other antigens in high salt, indicating that ionic interactions, probably with the phosphate groups of the Z-helix are more important for the naturally occurring antibody. Possible binding sites with these properties can be accommodated by features of the ZDNA helix (Fig. 5) in which an antibody combining site could encompass either one or both phosphate backbones. 

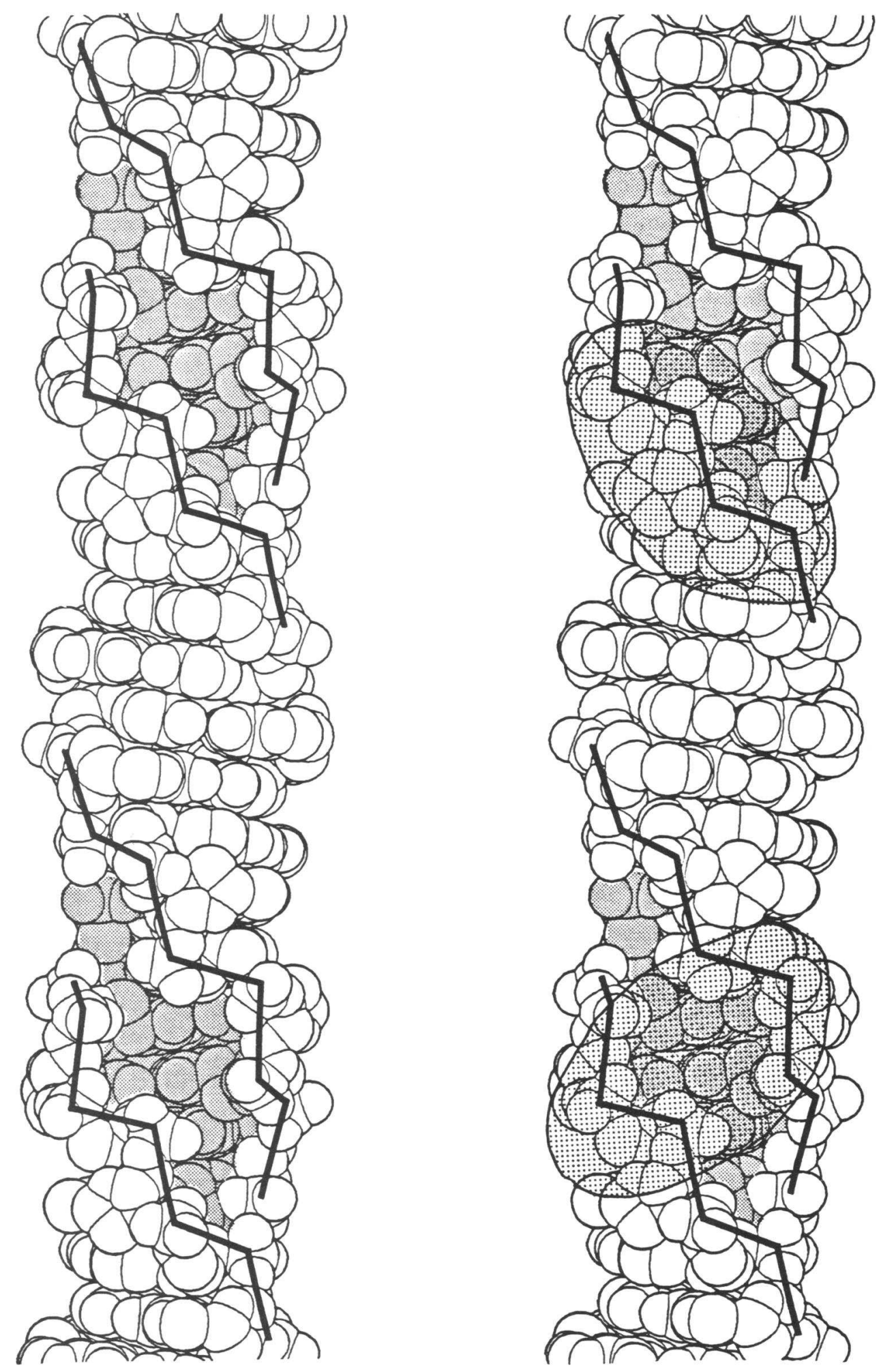

Figure 5 A computer drawing of the van der Waals surface of the molecular structure of ZDNA (14). The black zig-zag line connects the phosphate groups of the polynucleotide chain. The dotted ovals represent possible recognition sites for the Z-DNA-specific lupus antibody. The area of the antibody combining site is taken as $\sim 15 \AA \times 20 \AA$. 
It is also interesting to note that some patients' sera (Fig. 3A) bind to nDNA but not to poly (dG-dC) poly $(\mathrm{dG}-\mathrm{dC})$, although both are right-handed B-DNA helices. This adds to the growing evidence for sequence specific structural polymorphisms among righthanded DNA helices. Sera from lupus mice (MRL/ lpr) also reacted with nDNA but not poly (dG-dC) poly (dG-dC) (15). Antibodies raised to either poly (dG$\mathrm{dC}) \cdot \operatorname{poly}(\mathrm{dG}-\mathrm{dC})(15)$, poly $(\mathrm{dG}) \cdot \operatorname{poly}(\mathrm{dC})(6,21)$, or poly $(\mathrm{dC}-\mathrm{dA}) \cdot \operatorname{poly}(\mathrm{dG}-\mathrm{dT})(21)$ recognize their respective immunogen but not nDNA indicating that antibodies are capable of distinguishing the conformations of the polymers from the bulk of natural DNA.

The finding of a naturally occurring anti-Z-DNA specific antibody raises questions as to the origins of these antibodies as well as to the in vivo significance of Z-DNA. An animal immunized with Z-DNA in either the forms of $\mathrm{Br}-$ poly $(\mathrm{dG}-\mathrm{dC}) \cdot \operatorname{poly}(\mathrm{dG}-\mathrm{dC})(15)$ or $\operatorname{poly}\left(\mathrm{dG}-\mathrm{dm}^{5} \mathrm{C}\right) \cdot \operatorname{poly}\left(\mathrm{dG}-\mathrm{dm}^{5} \mathrm{C}\right)(21)$ produces a vigorous response. Z-DNA has been identified in eukaryotic chromosomes (16), but normal individuals do not have anti-Z-DNA antibodies, indicating that a normal individual is not exposed to an immunogenic form of Z-DNA. Since forces such as supercoiling (22-24) and proteins are probably required for holding DNA in vivo in a left-handed $\mathrm{Z}$ conformation, it is likely that the DNA presented to the immune system upon normal cell lysis probably does not contain Z-DNA. One theory to account for the appearance of antinDNA antibody in SLE in spite of the fact that nDNA has not been found to be reproducibly immunogenic in experimental animals is that the suppressor $\mathrm{T}$-cells that normally prevent the response to certain self-antigens are deficient in SLE patients $(25,26)$. More recent theories consider the presence of an abnormality in the idiotypic network that regulates B cells capable of producing immune network autoreactive antibodies (27). If this network is somehow disrupted, then these $B$ cells are expressed. This mechanism does not require the presence of an antigenic stimulus and consequently could account for the spontaneous production of antinDNA and anti-Z-DNA antibodies in SLE. Alternatively, it is conceivable that a different antigen might actually stimulate formation of antibodies that crossreact with nucleic acids. Monoclonal murine autoantibodies selected for anti-DNA activity have shown cross-reactivity with phospholipids, which resemble the phosphate backbone of denatured DNA (11). Numerous structures with varying spacing of repeating phosphate groups occur in nature, and may provide an immunogenic stimulus that DNA itself cannot provide.

\section{ACKNOWLEDGMENTS}

We thank Dr. G. J. Quigley for preparing the computer drawing of Z-DNA (Fig. 5).
This work was supported by grants from the National Institutes of Health (AM27232, AM11414, AM05577, CA04186, CA29753), the National Science Foundation, and the American Cancer Society. Dr. Möller and Dr. Nordheim are supported by grants from the Deutsche Forschungsgemeinschaft.

\section{REFERENCES}

1. Stollar, B. D. 1981. Anti-DNA antibodies. Clin. Immunol. Allergy. 1: 243-260.

2. Nakamura, R. M., and E. M. Tan. 1978. Recent progress in the study of autoantibodies to nuclear antigens. Hum. Pathol. 9: 85-91.

3. Madrid, F. F., and M. Mattioli. 1976. Antinuclear antibodies (ANA): Immunologic and clinical significance. Semin. Arthritis Rheumatism. 6: 83-124.

4. Schur, P. H. 1975. Complement in lupus. Clin. Rheum. Dis. 1: 519-543.

5. Agnello, V., D. Koffler, and H. G. Kunkel. 1973. Immune complex systems in the nephritis of SLE. Kidney Int. 3: 90-99.

6. Stollar, B. D. 1973. Nucleic acid antigens. The Antigens. Vol. I. M. Sela, editor. Academic Press, Inc., New York. 1-84.

7. Lamon, E. W., and J. C. Bennet. 1970. Antibodies to ribosomal ribonucleic acid (rRNA) in patients with systemic lupus erythematosus (SLE). Immunology. 19: 439-442.

8. Pinnas, J. L., T. D. Northway, and E. M. Tan. 1973. Antinucleolar antibodies in human sera. J. Immunol. 111: 996-1004.

9. Eilat, D., A. D. Steinberg, and A. N. Schechter. 1978 The reaction of SLE antibodies with native, singlestranded RNA. Radioassay and binding specificities. $J$. Immunol. 120: 550-557.

10. Kanai, Y., Y. Kawaminami, M. Miwa, T. Matsushima, T. Moroi, and R. Yokohari. 1977. Naturally occurring antibodies to poly(ADP-ribose) in patients with systemic lupus erythematosus. Nature (Lond.). 265: 175-177.

11. Lafer, E. M., J. Rauch, C. Andrzejewski, Jr., D. Mudd, B. Furie, B. Furie, R. S. Schwartz, and B. D. Stollar. 1981. Polyspecific monoclonal lupus autoantibodies reactive with both polynucleotides and phospholipids. $J$. Exp. Med. 153: 897-909.

12. Stollar, B. D., and M. Papalian. 1980. Secondary structure in denatured DNA is responsible for its reactions with antinative DNA antibodies of systemic lupus erythematosus sera. J. Clin. Invest. 66: 210-219.

13. Wang, A. H-J., G. J. Quigley, F. J. Kolpak, J. L. Crawford, J. H. van Boom, G. van der Marel, and A. Rich. 1979. Molecular structure of a left-handed double helical DNA fragment at atomic resolution. Nature (Lond.). 282: $680-686$

14. Wang, A. H-J., G. J. Quigley, F. J. Kolpak, G. van der Marel, J. H. van Boom, and A. Rich. 1981. Left-handed double helical DNA: Variations in the backbone conformation. Science (Wash. DC). 211: 171-176.

15. Lafer, E. M., A. Möller, A. Nordheim, B. D. Stollar, and A. Rich. 1981. Antibodies specific for left-handed ZDNA. Proc. Natl. Acad. Sci. USA. 78: 3546-3550.

16. Nordheim, A., M. L. Pardue, E. M. Lafer, A. Möller, B. D. Stollar, and A. Rich. 1981. Antibodies to lefthanded Z-DNA bind to interband regions of Drosophila polytene chromosomes. Nature (Lond.). 294: 417-422. 
17. Rigby, P. W. J., M. Dieckmann, G. Rhodes, and P. Berg. 1977. Labeling deoxyribonucleic acid to high specific activity in vitro by nick translation with DNA polymerase I. J. Mol. Biol. 113: 237-251.

18. Papalian, M., E. M. Lafer, R. Wong, and B. D. Stollar. 1980. Reaction of antinative DNA antibodies with native DNA fragments from 20 to 1,200 base pairs. J. Clin. Invest. 65: 469-477.

19. Cohen, A. S., W. E. Reynolds, E. C. Franklin, J. P. Kulko, M. W. Rogers, L. E. Shulman, and S. L. Wallace. 1971. Preliminary criteria for the classification of SLE. Bull. Rheum. Dis. 21: 643-648.

20. Lloyd, W., and P. H. Schur. 1981. Immune complexes, complement and anti-DNA in exacerbations of SLE. Medicine (St. Louis). 60: 208-217.

21. Lafer, E. M., A. Möller, A. Nordheim, A. Rich, and B. D. Stollar. 1982. Antibodies as probes for the sequence dependence of DNA secondary structure. Fed. Proc. 41: 1024.

22. Klysik, J., S. M. Stirdivant, J. E. Larson, P. A. Hart, and R. D. Wells. 1981. Left-handed DNA in restriction frag- ments and a recombinant plasmid. Nature (Lond.). 290: 672-677.

23. Peck, L. J., A. Nordheim, A. Rich, and J. C. Wang. 1982 Flipping of cloned $d(C G)_{n} \cdot d(C G)_{n}$ DNA sequences from right- to left-handed helical structures by salt, $\mathrm{Co}(\mathrm{III})$ or negative supercoiling. Proc. Natl. Acad. Sci. USA. 79: 4560-4564.

24. Nordheim, A., E. M. Lafer, L. J. Peck, J. C. Wang, B. D. Stollar, and A. Rich. 1982. Negatively supercoiled plasmids contain left-handed Z-DNA segments as detected by specific antibody binding. Cell. 31: 309-318.

25. Morimoto, C. 1978. Loss of suppressor T-lymphocyte function in patients with systemic lupus erythematosus (SLE). Clin. Exp. Immunol. 32: 125-133.

26. Fauci, A. S., A. D. Steinberg, B. F. Haynes and G. Whalen. 1978. Immunoregulatory aberrations in systemic lupus erythematosus. J. Immunol. 121: 14731479.

27. Talal, N. 1978. Autoimmunity and the immunologic network. Arthritis Rheum. 21: 853-861. 